\title{
POSITIVE FEEDBACKS BETWEEN FIRE AND NON-NATIVE GRASS INVASION IN TEMPERATE DECIDUOUS FORESTS
}

Stephanie A. Wagner and Jennifer M. Fraterrigo, Department of Natural Resources and Environmental Sciences, University of Illinois, Urbana, IL 61801

33 pages, including references, + 1 table, +4 figures, +1 appendix

Running title: Fire and grass invasion in deciduous forests

Keywords: exotic species; fire behavior; Japanese stiltgrass; Microstegium vimineum; plant invasion; prescribed fire; soil moisture

*Dr. Jennifer M. Fraterrigo (Corresponding author)

e-mail: jmf@illinois.edu

phone: 217-333-9428 / fax : 217-244-3219 


\section{Abstract}

2 Non-native grass invasions have the potential to change natural and prescribed fire regimes by

3 altering fuels, which in turn may promote further invasion. We examined if invasion by

4 Microstegium vimineum, a non-native annual grass, resulted in a positive invasion-fire feedback

5 in eastern deciduous forests managed with prescribed fire and how this response varied across

6 the landscape. Using paired invaded and uninvaded plots embedded in forest stands subjected to

7 prescribed fire, we quantified differences in fire intensity and fuel loads, and fire effects on $M$.

8 vimineum seedbank emergence, performance and spread. Invaded sites had less leaf litter and

9 fine woody fuels, and increased fire intensity. Although fire reduced emergence of $M$. vimineum

10 from the soil seedbank, sites subjected to prescribed fire had greater $M$. vimineum biomass and

11 higher recruitment than unburned sites. Soil moisture strongly modulated $M$. vimineum response

12 to fire, such that fire facilitated $M$. vimineum invasion more in wetter than drier sites. These

13 findings indicate that deciduous forests are vulnerable to positive invasion-fire feedbacks,

14 although the positive effect of fire may be less pronounced where soil moisture is limiting. The

15 interaction between soil moisture and fire effects can inform management decisions regarding

16 where to combine prescribed burning with intensive invasive control measures such as torching,

17 hand pulling, and herbicide application. 


\section{Introduction}

21 Fire is an important process for maintaining species diversity and ecosystem function in many

22 forest ecosystems across North America, including deciduous forests in the eastern US (Abrams,

23 1992; Royo et al., 2010; Stambaugh et al., 2015). Given its potential ecological benefits,

24 prescribed burning has been widely implemented as tool for managing and restoring eastern

25 deciduous forests with suppressed or altered fire regimes. Approximately one million ha are

26 burned under prescription annually in the US (Ryan et al., 2013), with a substantial fraction

27 occurring in eastern deciduous forests (Melvin, 2012).

28 While prescribed burning is useful for controlling woody understory growth, managing

29 fuels and promoting native vegetation (Burton et al., 2011), the use of fire in eastern deciduous

30 forests can also lead to less desirable changes (Matlack, 2013). Notably, prescribed burning can

31 promote the recruitment of non-native invasive plant species (Glasgow and Matlack, 2007;

32 Dibble et al., 2008; Kuppinger et al., 2010). Non-native invasive plant species with an

33 established seedbank tend to respond positively to post-fire conditions such as increased soil

34 temperatures, increased light levels, reduction of the litter layer, reduced competition and

35 increased available nitrogen. Once established, invasive plants can alter fire behavior by

36 changing fuel characteristics, which in turn can promote further invasion (Brooks et al., 2004).

37 The positive feedback between fire and invasion is well documented for non-native grasses (the

38 grass-fire cycle; D'Antonio and Vitousek 1992), and is attributable to their high flammability and

39 tendency to recover from disturbance more quickly than native species. In seasonally dry

40 woodlands in Hawaii, for example, invasion by the non-native grass Schizachyrium condensatum

41 results in increased fire frequency and non-native grass cover after fire (Hughes et al., 1991).

42 Similar impacts have been documented for non-native grass species in other ecosystems, 
43 including Bromus tectorum invasion in the US Great Basin (Balch et al., 2013), Andropogon

44 gayanus in northern Australian savannah (Setterfield et al., 2010), and Melinis minutiflora at the

45 Brazilian Cerrado savannah-forest ecotone (Hoffmann et al., 2004). In these grassland and dry

46 woodland systems, non-native invasive grasses have altered fuel characteristics by either

47 replacing less flammable, native vegetation or filling gaps between the naturally sparse

48 vegetation to create more continuous fuels (D'Antonio and Vitousek, 1992).

Although it is speculated that grass invasion of forests will increase flammability, few

50 studies have investigated the interaction between grass invasion and fire in eastern deciduous

51 forests (Dibble et al., 2008). The grass-fire cycle has predominantly been studied in dry

52 woodlands and grasslands, which have different fuel characteristics than forests. Whereas

53 grasses and forbs are the main fuel source in grassland communities, downed material from the

54 overstory is the major contributor to the fuel load in most forest systems. Given this, understory

55 grass invasion may have little influence on forest fire behavior, resulting in weak feedback

56 between fire and invasion. At the same time, grasses have several unique characteristics that

57 distinguish them from forest fuels, including a high surface area to volume ratio which allows for

58 rapid drying, and low compactness which allows for more oxygen to mix with the fuel (DeBano

59 et al. 1998). While both grasses and forest litter provide continuous horizontal fuels, the

60 relatively slower drying that characterizes forest fuels can make them functionally discontinuous

61 if the fuels are too wet to carry fire, whereas grass-invaded forests may have high functional

62 continuity of fuels due to the rapid drying of grasses. As a result, grass invasion might contribute

63 to changes in forest fire behavior despite the dominance of overstory fuels.

64 For this study, we investigate the interaction between fire and grass invasion of eastern

65 deciduous forests using Microstegium vimineum (Trin.) A. Camus, an annual C4 species native 
to southeastern Asia (Fairbrothers and Gray, 1972). In its native range, $M$. vimineum occupies a

67 variety of temperate habitats including forests, forest edges, and riparian areas, and fires are

68 common during the dry winter months (Flory et al., 2011; Fischer et al., 2013). It occurs in

69 similar habitats in the eastern US, and currently ranges from Texas to Massachusetts (USDA,

70 2015). By forming dense lawns in the forest understory, $M$. vimineum can significantly alter the

71 understory community and suppress tree seedling growth (Oswalt et al., 2007; Marshall et al.,

72 2009; Flory and Clay, 2010; Brewer, 2011). It can also affect ecosystem processes by altering

73 microbial activities and accelerating nitrogen and carbon cycling (Ehrenfeld et al., 2001; Kourtev

74 et al., 2003; Fraterrigo et al., 2011; Craig et al., 2015). Due its impacts on forest ecosystems,

75 there is a need to characterize conditions that are facilitating the invasion success of $M$. vimineum

76 and use this information to control established populations.

Generally, M. vimineum shows a positive response to disturbance, including fire, litter

78 removal, and logging (Glasgow and Matlack, 2007; Oswalt and Oswalt, 2007; Nelson et al.,

79 2009; Emery et al., 2013). Specifically, post-burn conditions have been shown to have a positive

80 effect on M. vimineum growth (Glasgow and Matlack, 2007). Although M. vimineum

81 germination and seedling density is reduced immediately following fire, these negative effects on

82 stem density do not persist in the following growing season (Emery et al., 2013). In addition to

83 responding positively to disturbance, $M$. vimineum performance is sensitive to resource

84 gradients. $M$. vimineum growth and reproductive output is reduced in low light environments,

85 under low nitrogen conditions, and in water-limited areas (Claridge and Franklin, 2002;

86 Huebner, 2010a; Ross et al., 2011; Warren et al., 2011). These resource gradients may interact

87 with fire regimes to amplify or weaken plant response to fire. By examining the interaction 
88 between fire and $M$. vimineum invasion across resource gradients, we can better identify areas

89 where prescribed fire is more likely to promote invasion.

90 The overall objective of this study was to evaluate the interaction between fire and the

91 invasion of a non-native annual grass, Microstegium vimineum, in eastern deciduous forests

92 across a range of environmental and fuel conditions. Specifically, we asked: (1) How does $M$.

93 vimineum invasion influence fuels and fire intensity? and (2) How does prescribed fire affect

94 emergence from the $M$. vimineum seedbank and the performance and spread of $M$. vimineum

95 across environmental gradients? We expected that grass invasion would increase fine fuel loads,

96 and, in turn, increase fire intensity because of the high flammability of fine fuels. We further

97 expected that fire would reduce emergence of $M$. vimineum from the seedbank, but that this

98 negative effect would be outweighed by enhanced recruitment over the longer-term. Because $M$.

99 vimineum performs better in mesic conditions, we predicted that low soil moisture would weaken

100 the positive feedback between fire and M. vimineum invasion.

101

102 2. Methods

1032.1 Study Site

104 We conducted this work at the Shawnee National Forest (SNF) and Dixon Springs State Park 105 (DSSP) located in the Central Hardwood Region between the Mississippi and Ohio rivers in far 106 southern Illinois. In this unglaciated region, there are distinct landscape gradients from mesic, 107 forested ravines to drier, upland forest. Mean temperature is $31^{\circ} \mathrm{C}$ in the summer and $8^{\circ} \mathrm{C}$ in the 108 winter with a mean annual precipitation of $125 \mathrm{~cm}$. During the study period (2011-2013), mean 109 summer temperature was $26^{\circ} \mathrm{C}$ and total annual precipitation ranged from 42 to $88 \mathrm{~cm}$ 110 (http://www.ncdc.noaa.gov). The uplands in this region are dominated by mixed oak (Quercus 
$111 s p$. ) and hickory (Carya sp.) forests and the mesic areas are comprised of a wide range of

112 hardwoods including tulip poplar (Liriodendron tulipifera), beech (Fagus grandifolia), black

113 walnut (Juglans nigra), bitternut hickory (Carya cordiformis), red oak (Quercus rubra),

114 Kentucky coffee tree (Gymnocladus dioicus), Ohio buckeye (Aesculus glabra), honey locust

115 (Gleditsia triacanthos), basswood (Tilia americana), white ash (Fraxinus americana), and sugar

116 maple (Acer saccharum) (Mohlenbrock, 1982). In addition to the hardwood communities, the

117 USDA Forest Service also maintains loblolly pine (Pinus taeda) and shortleaf pine (Pinus

118 echinata) dominated stands. The USDA Forest Service regularly conducts prescribed burns at

119 SNF to reduce fuels, stimulate the growth of native herbaceous plants and increase oak-hickory

120 regeneration. Each year between October and April, an average of 2,000 ha is burned. $M$.

121 vimineum was first documented in the area prior to 1986 and frequently occurs near roads, trails,

122 and streams, which are all common dispersal corridors for M. vimineum (Mohlenbrock, 1986;

123 Christen and Matlack, 2009).

124

$125 \quad 2.2$ Study design

126 We evaluated the interaction between M. vimineum invasion and fire by conducting

127 several detailed studies in multiple burn units and adjacent unburned forest stands. To determine

128 fire effects on invasive grass performance, we compared grass recruitment, biomass, seed

129 production, and advancement of the invasion front in burn units prior to burning and in adjacent

130 unburned forest stands. In a subset of these burn units, we characterized pre- and post-burn fuel

131 beds and measured fire residence times in paired invaded-uninvaded plots to determine how

132 invasion influenced fuels and fire behavior. We also quantified seedbank emergence following

133 burning to assess short-term fire effects on grass invasion. Collectively, the results of these 
134 studies provided insights into the pathways by which grass invasion and fire feedback to each

135 other, allowing us to test the different components of the grass-fire cycle in eastern deciduous

136 forests.

137 Burn units were selected to represent the range of variation in soil moisture conditions

138 present in the study area, ranged in size from 15 to 1298 ha, and were between 4 and $41 \mathrm{~km}$ apart

139 (Table A1). When the study began, the burn units had been last burned in either 2009, 2010, or

140 2011; thus, performance and pre-burn fuel measurements were done 1-4 years since the last fire.

141 Adjacent unburned areas were selected such that they were comparable to burn units with respect

142 to elevation and terrain but lacked a history of management by fire. Detailed methods for each

143 study are provided below.

$144 \quad$ 2.2.1 M. vimineum performance and spread

145 To assess the influence of fire on M. vimineum performance, we established 17 plots in burn

146 units and paired them with 17 plots in adjacent unburned stands ( $\mathrm{n}=34$ plots total; Table A1).

147 Approximately half of the plots were established in 2011 (nine in burn units and nine in

148 unburned stands), with the remaining plots established in 2012. Although M. vimineum is a

149 prolific seeder, local dispersal of $M$. vimineum populations is slow with populations spreading

150 less than $25 \mathrm{~cm}$ annually (Rauschert et al., 2010). This slow spread coupled with high local

151 recruitment results in discrete invasion edges. The study plots were installed near these discrete

152 invasion edges to control for time since invasion. Each plot consisted of two parallel 3-m

153 transects that began at a discrete invasion edge with $0.25 \times 0.25-\mathrm{m}$ subplots located 1,2 , and $3 \mathrm{~m}$

154 from the edge, moving into the invaded patch (sensu Warren et al. 2011).

155 In August of the year plots were established, the leaf litter, aboveground biomass of $M$.

156 vimineum, and aboveground biomass of other herbaceous plants and woody seedlings were 
157 collected from the subplots along one of the two transects in each plot. Samples were dried to

158 constant mass in a $60{ }^{\circ} \mathrm{C}$ oven and weighed. We counted flowering stems in the subplots of the

159 unaltered transects during September of the year plots were established. In October, after seed set

160 and before seed release, five randomly selected stalks were collected from the unaltered transects

161 and seeds were counted in the lab to estimate seed production. In the following spring, we

162 quantified recruitment by counting the number of new stems in all subplots along both harvested

163 and unaltered transects. For all responses, subplot data were pooled, yielding one value per plot.

164 Prior to litter and biomass collection, we measured light and soil moisture along transects

165 selected for destructive harvest. Light levels were measured over each subplot and under a

166 reference full light condition using a LiCor quantum line sensor (LI-COR, Inc. Lincoln,

167 Nebraska USA). The reference light measurement was used to calculate the percent of full sun

168 for each subplot. Soil moisture was measured from three locations within each subplot using a

169 Time Domain Reflectometry probe (Decagon 5TM Soil Moisture Sensor, Decagon Devices Inc.,

170 Pullman, WA, USA). All data were pooled by plot.

171 To determine fire effects on M. vimineum advancement, we installed three spread

172 transects in each of the nine paired plots established in burn units and adjacent unburned stands

173 in 2011 ( $\mathrm{n}=18$ plots total). The spread transects were located within $10 \mathrm{~m}$ of the performance

174 plots and consisted of 50-cm wide rows of pin flags starting at the invasion edge and moving

175 perpendicular into the uninvaded area. The invasion edge was marked in July 2011, and

176 advancement was measured from the marked edge to the farthest $M$. vimineum plant along each

177 transect in August 2012. Distances were averaged by plot. We also determined the slope of each

178 plot using a GIS and a 10-m DEM.

$179 \quad$ 2.2.2 Forest fuels and fire intensity 
180 In July-August of 2012, we measured fuels in 20 pairs of invaded and uninvaded plots ( $\mathrm{n}=40$

181 plots total) distributed across seven of the burn units used in the performance study plus one

182 additional site (DiSp; Table A1). Each fuel plot consisted of three 17-m fuel transects radiating

183 from a central point at $0^{\circ}, 120^{\circ}$, and $240^{\circ}$ azimuths (Fig. A1). Along each transect, starting one

184 meter from the plot center, intersecting woody fuels were inventoried using Brown's line

185 intercept method (Brown, 1974) with 1-hour fuels ( $<0.64 \mathrm{~cm}$ in diameter) counted along two

186 meters of the transect, 10 -hour fuels $(0.64-2.5 \mathrm{~cm}$ in diameter) counted along four meters, 100 -

187 hour fuels $(2.5-7.6 \mathrm{~cm}$ in diameter) counted along eight meters, and 1000-hour fuels $(>7.6 \mathrm{~cm})$

188 counted along 16 meters of the transect. The diameters of all the 1000-hour fuels were measured.

189 Four subplots $(25 \times 25 \mathrm{~cm}$ ) were established along each transect. Leaf litter (not including $M$.

190 vimineum or other plants that were alive from July to August) and duff were harvested from

191 these subplots, dried in a $60^{\circ} \mathrm{C}$ oven, and weighed.

192 To determine what fuel types were consumed by prescribed fires, 11 sets of paired plots

193 ( $\mathrm{n}=22$ plots total) were resampled in spring of 2013 after burning using identical methods (Table

194 A1). Prior to burning, data loggers and type K thermocouples were installed in all but two of

195 these pairs ( $\mathrm{n}=1$ per plot) (Table A1) to measure fire intensity. Thermocouples were placed at the

196 soil surface, beneath the forest floor. Fire did not reach one of the invaded plots and this plot was

197 not included in the analysis. Temperature was recorded every ten seconds and was used to

198 calculate fire residence time, defined as the number of minutes over $60^{\circ} \mathrm{C}$. We used this

199 temperature threshold because it is a temperature at which cell death can occur in plants (Levitt,

200 1980).

201 2.2.3 Seedbank emergence 
202 We collected soil twice from each of 23 invaded plots in the spring of 2013 to assess the short-

203 term effects of fire on the M. vimineum seedbank. Twelve plots were located in the burn units

204 where fuels were measured (Table A1). In these plots, soil was collected before and within two

205 days after burning. The remaining eleven plots were located in adjacent unburned areas and were

206 sampled at the same time as the neighboring burn unit. For all plots, the time between sampling

207 periods depended on when a burn took place and ranged from 7 - $22 \mathrm{~d}$.

208 To account for spatial heterogeneity in the seedbank, we used a "many small samples"

209 approach (Gross, 1990). This involved pooling 10 subsamples collected with a soil corer $(6 \mathrm{~cm}$

210 diameter, $4 \mathrm{~cm}$ deep) in each plot. The first set of subsamples was collected along transects at 60

$211 \mathrm{~cm}$ and $110 \mathrm{~cm}$ from the plot center at $0^{\circ}, 18^{\circ}, 36^{\circ}, 54^{\circ}$, and $72^{\circ}$ azimuths, and the second set of

212 subsamples was collected at $70 \mathrm{~cm}$ and $220 \mathrm{~cm}$ at the same azimuths. Only the shallow seedbank

213 was collected because low intensity prescribed fires typically do not heat the soil below a few

214 centimeters (Heyward, 1938; DeBano et al., 1998; Iverson and Hutchinson, 2002). Composited

215 seedbank samples were returned to the greenhouse and spread thinly over trays filled with sterile

216 course sand. Trays were monitored weekly for emerging M. vimineum stems, and emerging

217 stems were removed from the tray. Each tray was retained in the greenhouse after emergence

218 peaked and two weeks had passed without new emerging individuals.

2202.3 Data Analysis

221 We used linear mixed models to evaluate differences in M. vimineum biomass, recruitment, and

222 seed production with burn treatment, analyzing count data using generalized linear mixed models

223 with a log-link function. In addition to burn treatment, $M$. vimineum performance models

224 included soil moisture, litter mass, light, and all interactions as fixed effects. Pair was nested 
225 within burn unit and both pair and burn unit were incorporated as random effects. For models

226 that included interactions with continuous covariates, the $1^{\text {st }}$ and $3^{\text {rd }}$ quantiles were used to

227 estimate the interaction. These models were compared using AICc values for the mixed models

228 and pseudo AICc values for the generalized linear mixed models. The models with the lowest

229 AICc values were used as the best fit.

230 We tested for differences in M. vimineum advancement between burned and unburned 231 plots using linear mixed models, with pair included as a random effect. Covariates included in

232 these models as fixed effects were litter mass (determined from co-located performance plots),

233 slope, and burn treatment. These models were compared with AICc values.

$234 \quad$ Pre-burn fuel composition was compared between invaded and uninvaded plots using

235 generalized linear mixed models and a log-link function for count data. Random variables

236 included the intercept and pair, which was nested within burn unit (also a random variable);

237 invasion treatment was included as a fixed effect. To determine which fuel types were consumed

238 and test for differences in fuel consumption between invaded and uninvaded plots, data from the

239 fuel plots sampled before and after the spring 2013 burns were analyzed as a before-after

240 control-impact design using a generalized linear mixed model with a log-link for count response

241 variables (McDonald et al., 2000). Pair was nested within burn unit and both pair and burn unit

242 were incorporated as random effects. For the before-after control-impact design, the fixed effects

243 included invasion status, burn treatment (expressed as a before-after effect), and the interaction

244 between invasion status and burn treatment. Because there are several variables that we would

245 expect to contribute to fire intensity, we compared models which included invasion status, pre-

246 burn fuels (separated by type), and slope as fixed effects. 
Seed bank emergence was analyzed as a before-after control-impact design using a generalized linear mixed model with a log link (McDonald et al., 2000). Plot was nested in site and both plot and site were included as random effects. The fixed effects included the burn

250 treatment, time (pre-burn vs. post-burn), and the interaction between burn treatment and time.

251 All analyses were performed in SAS (SAS Institute Inc. 2013) using the proc glimmix or proc 252 mixed functions.

253

254

255

256

257

258

259

260

261

262

263

264

265

266

267

268

269

270

271

\section{Results}

3.1 Fire effects on M. vimineum performance

M. vimineum performed better in stands managed with prescribed fire. M. vimineum biomass was significantly higher in burned plots $\left(\mathrm{F}_{1,15}=3.82, \mathrm{p}=0.07\right)$ and areas of high soil moisture $\left(\mathrm{F}_{1,15}=19.9, \mathrm{p}<0.001\right)$. A significant interaction between soil moisture and burn treatment indicated that soil moisture modulated the positive effects of burning on M. vimineum biomass $\left(\mathrm{F}_{1,15}=6.98, \mathrm{p}=0.02\right)$. When estimated using soil moisture values for drier and wetter sites $\left(1^{\text {st }}\right.$ and $3^{\text {rd }}$ quantiles of the soil moisture data), M. vimineum biomass was $214 \%$ and $135 \%$ higher in burned and unburned plots (resp.) situated in wetter sites compared to drier sites (Fig.1). Seed production per stalk did not vary with burn treatment $\left(\mathrm{F}_{1,15}=3.82, \mathrm{p}=0.10\right)$; however, it was positively related to soil moisture in burned plots and unrelated to soil moisture in unburned plots $\left(\mathrm{F}_{1,15}=3.82, \mathrm{p}=0.06\right.$; Fig. 2). There was no relationship between M. vimineum advancement and burn treatment or litter mass. There was, however, a positive relationship between slope and $M$. vimineum spread $\left(\mathrm{F}_{1,8}=24.5, \mathrm{p}=0.001\right)$. Slope and burn treatment did not interact $\left(\mathrm{F}_{1,6}=0.04, \mathrm{p}=0.84\right)$.

M. vimineum recruitment was significantly higher in burned plots, which had 37\% more spring stems than unburned plots $\left(\mathrm{F}_{1,49}=174.8, \mathrm{p}<0.001\right)$. Comparing recruitment in burned 
272 and unburned harvested plots enabled us to test for additive effects of fire on M. vimineum

273 invasion; that is, effects of fire beyond those associated with removal of the litter layer and

274 herbaceous understory. Burning plus litter and biomass removal had a minor but significant

275 effect on spring stem emergence, which was 13\% higher in burned than unburned plots in the

276 spring following harvest $\left(\mathrm{F}_{1,49}=30.9, \mathrm{p}<0.001\right.$, Fig. 3$)$.

277 The benefit of high spring emergence in burned plots persisted throughout the growing

278 season. In August, the mean number of stems per plot was $93.9( \pm 15.2 \mathrm{SE})$ and $61.8( \pm 10.1 \mathrm{SE})$

279 in burned and unburned plots, respectively $\left(\mathrm{F}_{1,17}=137.5, \mathrm{p}<0.001\right)$. In addition to burn

280 treatment, the best model for the number of stems in August included soil moisture, litter mass,

281 an interaction between soil moisture and litter mass, and an interaction between burn treatment

282 and soil moisture. According to this model, the number of stems in August was positively related

283 to soil moisture at burned sites $\left(\mathrm{F}_{1,13}=104.7, \mathrm{p}<0.001\right)$ and unrelated at unburned sites. At

284 wetter sites ( $3^{\text {rd }}$ quantile of the soil moisture data), the number of $M$. vimineum stems was $252 \%$

285 higher in burned than unburned plots. There was less of a difference between burned and

286 unburned plots at drier sites ( $1^{\text {st }}$ quantile of the soil moisture data) with $107 \%$ more stems in

287 burned plots. There was a positive relationship between litter mass and the number of stems

$288\left(\mathrm{~F}_{1,13}=6.39, \mathrm{p}=0.03\right)$, and between litter mass and soil moisture $\left(\mathrm{F}_{1,13}=19.2, \mathrm{p}<0.001\right)$.

$290 \quad 3.2$ Forest fuels and fire intensity

291 Prior to burning, fuel load averaged $40.1 \mathrm{Mg} / \mathrm{ha}$ (Table 1). The 1000-hour fuels were the largest 292 component of the fuel bed, comprising approximately $64 \%$ of the total fuel load. The 100 -hour 293 fuels comprised approximately $11 \%$ of the total fuel load and litter comprised $17 \%$ of the total 294 average fuel load. Fuel composition varied between invaded and uninvaded plots (Table 1). 
Invasion was associated with less litter mass and fine woody fuels, and more 1000-hour fuels. In

296 the uninvaded plots, there was 38\% more leaf litter $\left(\mathrm{F}_{1,19}=27.2, \mathrm{p}<0.0001\right)$ and $13 \%$ more 1 -

297 hour fuels $\left(\mathrm{F}_{1,19}=24.4, \mathrm{p}<0.0001\right)$. There was also a trend for $6 \%$ more 10 -hour fuels and $8 \%$

298 more 100-hour fuels in uninvaded plots $\left(\mathrm{F}_{1,19}=3.25, \mathrm{p}=0.09\right.$ and $\mathrm{F}_{1,19}=1.70, \mathrm{p}=0.05$,

299 respectively). In contrast, there was $106 \%$ more 1000 -hour fuels based on count $\left(\mathrm{F}_{1,19}=6.11, \mathrm{p}=\right.$

300 0.02) and diameter $\left(\mathrm{F}_{1,19}=5.58, \mathrm{p}=0.03\right)$ in the invaded plots with a trend for an average of 9.7

$301 \pm 6.5 \mathrm{SE} \mathrm{Mg/ha} \mathrm{more} \mathrm{1000-hour} \mathrm{fuels} \mathrm{in} \mathrm{the} \mathrm{invaded} \mathrm{plots}\left(\mathrm{F}_{1,19}=1.11, \mathrm{p}=0.30\right)$.

Across all fuel types assessed, consumption did not vary between invaded and uninvaded

303 plots (litter: $F_{1,30}=1.9, p=0.18$; duff: $F_{1,30}=0.01, p=0.91 ; 1$-hour: $F_{1,30}=0.01, p=0.94 ; 10$ -

304 hour: $F_{1,30}=0.66, p=0.42 ; 100$-hour: $F_{1,30}=1.5, p=0.23 ; 1000$-hour: $F_{1,30}=0.02, p=0.90$ ).

305 Leaf litter, 1-hour, and 10-hour fuels were reduced by 45-65\% after burning, indicating that these 306 fuel classes were combusted during the burn (litter: $F_{1,30}=25.4, p<0.001$; 1 -hour: $F_{1,30}=82.9$, p $307<0.001 ; 10$-hour: $\left.\mathrm{F}_{1,30}=52.19, \mathrm{p}<0.001\right)$

308 Maximum recorded fire temperatures at the soil surface ranged from $75.7^{\circ} \mathrm{C}$ to $299.8^{\circ} \mathrm{C}$, 309 with an average of $407 \mathrm{~s}( \pm 143 \mathrm{SE})$ spent above $60{ }^{\circ} \mathrm{C}$. Fire residence time over $60{ }^{\circ} \mathrm{C}$ was 310 higher in invaded than uninvaded plots (invaded $=433 \pm 50 \mathrm{~s}$, uninvaded $=397 \pm 44 \mathrm{~s} ; \mathrm{F}_{1,5}=$

$31126.9, \mathrm{p}<0.01)$, but depended strongly on pre-burn litter mass $\left(\mathrm{F}_{2,5}=16.7, \mathrm{p}<0.01\right)$. At invaded

312 sites, fire residence times increased with increasing leaf litter mass, whereas in uninvaded areas, 313 fire residence times decreased with increasing leaf litter mass $\left(\mathrm{F}_{2,5}=16.7, \mathrm{p}<0.01\right)$.

3153.3 Fire effects on seedbank emergence

316 Prior to fire, invaded study plots did not differ with respect to the number of $M$. vimineum seeds

317 that emerged in the greenhouse (burned: mean $=44.8 \pm 10.6$; unburned: mean $=46.9 \pm 14.5$ ). 
318 After exposure to fire, however, 13\% fewer seeds emerged from burned, invaded plots (burned:

319 mean $=17.6 \pm 4.2$; unburned: mean $=24.6 \pm 7.7)\left(\mathrm{F}_{1,25}=8.50, \mathrm{p}<0.01\right.$, Fig. 4).

\section{4. Discussion and conclusions}

322 A positive feedback between grass invasion and fire can accelerate the invasion process.

323 Although the grass-fire cycle is well documented in grassland and dry woodland systems, it is 324 unclear how this cycle operates in eastern deciduous forests where the tree community plays a 325 dominant role in shaping the fuel characteristics. We found that fire had strong positive effects 326 on M. vimineum biomass and recruitment, and a modest negative effect on emergence from the 327 seedbank. Overall, this suggests that fire promotes the invasion of $M$. vimineum in eastern

328 deciduous forests. We also found that $M$. vimineum invasion increases fire residence times, 329 which supports the idea that there is a positive feedback between fire and invasion by $M$. 330 vimineum in eastern deciduous forests.

331 Invaded plots had lower amounts of fine fuels, particularly leaf litter, which likely

332 initially promoted M. vimineum establishment. Other studies have found that leaf litter can serve 333 as a physical barrier to M. vimineum establishment (Oswalt and Oswalt, 2007). Invaded plots

334 also had higher amounts of 1000-hr fuels, which corresponded with the number of rotten and 335 solid downed logs. Canopy disturbances that increase light availability can influence the 336 invasibility of an area (Davis and Pelsor, 2001), and M. vimineum has been shown to respond 337 positively to increased light (Nelson et al., 2009; Cheplick, 2010). Therefore, it is likely that the 338 increased 1000-hour fuels in invaded plots are indicative of canopy disturbance. Although invasion was not associated with higher fine fuel loads, we observed an

340 increase in fire residence times in invaded stands. Similarly, Emery et al. (2011) found that 
341 invasion by $M$. vimineum increased fire temperatures by $300-400{ }^{\circ} \mathrm{C}$ at an extensively invaded

342 forest in central Indiana, USA. The effect size was not as large at SNF possibly because SNF is

343 less productive overall than the site where Emery et al. (2011) worked. In our study, fire

344 residence time was positively related to litter mass at invaded sites while fire intensity was

345 negatively related to litter mass at uninvaded sites. Since there was no difference in fuel

346 consumption between invaded and uninvaded plots, and uninvaded plots had more pre-burn

347 litter, the negative relationship between litter depth and fire intensity at the soil surface in

348 uninvaded plots is likely an artifact of remaining unburned litter insulating the soil surface where

349 the temperature sensors were located. Despite the reduced litter layer and fine woody fuels in the

350 invaded plots, we still found an increase in fire intensity in the invaded plots which, as suggested

351 by Dibble et al. (2007), could be linked to the characteristics of $M$. vimineum as a fuel that is

352 continuous and easily ignitable.

353 Despite the relatively low fire intensities measured during prescribed fires at SNF,

354 temperatures at the soil surface were elevated enough to reduce $M$. vimineum emergence by $13 \%$.

355 This finding is consistent with previous studies showing that exposure to direct flame and high

356 fire temperatures inhibit M. vimineum germination (Emery et al., 2011; Ward and Mervosh,

357 2012; Emery et al., 2013). Emery et al. (2013) found an approximately 80\% reduction in $M$.

358 vimineum germination the year following a spring burn compared to the subsequent year, which

359 suggests that increased fire intensity can lead to increased seed mortality.

360 Despite lower emergence from the seedbank in the spring following prescribed fire,

361 burned areas showed improved M. vimineum performance in terms of biomass, recruitment, and

362 seed production. Emery et al. (2013) also found that M. vimineum performance improved

363 following fire and overwhelmed the negative effects of fire on germination. Removing litter and 
364 herbaceous competitors had only a small effect on recruitment in burned sites compared to

365 unburned sites. This suggests that fire facilitates invasion primarily by reducing barriers to

366 recruitment, consistent with other studies showing that litter removal strongly promotes $M$.

367 vimineum establishment (Glasgow and Matlack, 2007; Oswalt and Oswalt, 2007; Marshall and

368 Buckley, 2008). In contrast, $M$. vimineum spread was predicted by slope. Other studies have

369 shown that $M$. vimineum is more prevalent downslope from roads, a common dispersal corridor

370 (Kuhman et al., 2010), and that spread is slow due to dispersal limitation and not strongly

371 correlated to resource gradients such as soil moisture and light (Christen and Matlack, 2009;

372 Huebner, 2010b; Rauschert et al., 2010).

373 To persist after fire, plant species use various strategies that include evading, resisting,

374 and enduring fire. In the case of M. vimineum, we have shown that seeds which are exposed to

375 fire have a reduced probability of emerging; however, post-burn litter reduction promotes

376 establishment. Warren et al. (2012) showed that M. vimineum overcomes seed limitation by

377 having high per capita seed production, and it is likely that the high propagule pressure combined

378 with a reduced litter layer could be allowing M. vimineum to overcome the $13 \%$ reduction in

379 emergence from the seedbank post-fire. The timing of seed arrival in relationship to fire is

380 another mechanism which can influence post-fire invasion (DeGasperis and Motzkin, 2007).

381 Previous studies highlight the importance of propagule arrival on $M$. vimineum success after

382 prescribed fire. When seeds were sown after a burn treatment, Glasgow and Matlack (2007)

383 found that germination increased. Additionally, Flory and Lewis (2009) found that M. vimineum

384 germination could be reduced by timing prescribed fire to coincide with seed production.

385 Overall, the positive influence of fire on establishment outweighs the direct negative effect on

386 emergence from the seedbank, favoring the growth of $M$. vimineum populations. Consistent with 
this conclusion, demographic modeling shows that one year after prescribed fire there was no

388 effect of burning on M. vimineum population growth despite a reduction in population growth

389 immediately following the fire (Emery et al., 2013).

$390 \quad$ By demonstrating that $M$. vimineum increases fire intensity and responds positively to

391 burning, our study supports the existence of the grass-fire cycle and a positive feedback between

392 fire and invasion in eastern deciduous forests. However, because M. vimineum's response to fire

393 varies with soil moisture, the strength of this feedback will differ across forested landscapes.

394 Previous studies have shown that soil moisture has a positive influence on M. vimineum

395 performance (Touchette and Romanello, 2010; Warren et al., 2011). In addition to detecting a

396 positive relationship between soil moisture and M. vimineum performance, we found that soil

397 moisture interacted with burn treatments such that seed production was positively related to soil

398 moisture at burned sites and unrelated to soil moisture at unburned sites. The weak response of

399 M. vimineum to soil moisture gradients at unburned sites suggests that another resource or a

400 biological interaction is limiting $M$. vimineum growth at the unburned sites. Considering that fire

401 can increase light, reduce competition, and temporarily increase available nitrogen, and

402 considering that $M$. vimineum performance can be limited by light, nitrogen, and competition

403 (Huebner, 2010a; Ross et al., 2011; Fraterrigo et al., 2014), it is likely that one or more of these

404 factors is limiting M. vimineum more than soil moisture at unburned sites. Furthermore, fire 405 generally reduces soil moisture in forests through various mechanisms, including increased 406 evaporative water loss due to the reduced litter layer, darkened soil, and increased amount of 407 radiant energy reaching the forest floor (Neary et al., 1999). Consequently, burning in drier areas 408 may lead to greater water limitation of plant growth. This finding has important implications for 409 balancing prescribed burning objectives and control of $M$. vimineum invasion. Given that 
410 prescribed fire is a useful and cost effective way to manage fuels, promote native vegetation, and

411 improve timber resources (Abrams, 1992; Burton et al., 2011), it is unrealistic to recommend that

412 this tool not be used due to the negative impacts of fire on M. vimineum control. Within one

413 management area, burning at drier sites will not give M. vimineum the same advantage as

414 burning wetter sites, allowing managers to focus labor intensive invasive control methods, such

415 as hand pulling, torching, and herbicide applications, in the wetter areas.

416

\section{5. Acknowledgements}

418 This research was supported by the USDA McIntire-Stennis Program and the University of

419 Illinois. We are grateful for field and lab assistance from Scott Crist, Jim Kirkland, Scott Cinel,

420 Sean Hill, and Yiwei Li. We thank the USDA Forest Service at Shawnee and the Illinois DNR at

421 Dixon Springs for allowing access to their land.

422

423 6. Appendix

424 Descriptive information for experimental plots and schematic of the fuel characterization

425 transects. 
426 Table 1 Fuel loads (mean \pm SE) for invaded and uninvaded plots before and after prescribed fire.

\begin{tabular}{llllll}
\hline Fuel Type & \multicolumn{2}{c}{ Pre-burn (Mg/ha) } & & \multicolumn{2}{c}{ Post-burn (Mg/ha) } \\
\cline { 2 - 3 } \cline { 5 - 6 } & Invaded plots & Uninvaded plots & & Invaded plots & Uninvaded plots \\
\hline Duff & $1.58 \pm 1.90$ & $2.16 \pm 2.11$ & & $3.21 \pm 1.62$ & $3.25 \pm 1.26$ \\
Litter & $5.83 \pm 2.69$ & $8.04 \pm 2.44$ & & $4.96 \pm 1.80$ & $5.46 \pm 1.36$ \\
1 hour & $0.45 \pm 0.21$ & $0.64 \pm 0.27$ & & $0.31 \pm 0.18$ & $0.45 \pm 0.27$ \\
10 hour & $0.60 \pm 0.45$ & $0.70 \pm 0.42$ & & $0.42 \pm 0.38$ & $0.52 \pm 0.41$ \\
100 hour & $4.11 \pm 3.67$ & $4.78 \pm 3.71$ & & $3.74 \pm 2.97$ & $5.07 \pm 3.88$ \\
1000 hour & $30.5 \pm 32.8$ & $20.8 \pm 28.7$ & & $26.6 \pm 30.5$ & $33.4 \pm 26.2$ \\
Total & $38.5 \pm 49.4$ & $29.7 \pm 40.6$ & & $33.9 \pm 44.0$ & $27.2 \pm 37.1$ \\
\hline
\end{tabular}

427

428

429 
431

432 Fig. 1 The relationship between $M$. vimineum biomass and soil moisture by burn treatment. The 433 thin lines show the SE around the mean.

434

435 Fig. 2 The relationship between $M$. vimineum seed production and soil moisture by burn

436 treatment. The dashed lines show the SE around the mean.

437

438

439 herbs, by burn treatment.

440

441 Fig. 4 Mean ( \pm SE) number of emerging $M$. vimineum sprouts from the seedbank of burned and

442 unburned stands. Seedbank samples were collected before and after prescribed burn in the

443 burned stands.

444

445

446

447

448

449

450

451

452 


\section{References}

454 Abrams, M.D., 1992. Fire and the development of oak forests. Bioscience 42, 346-353.

Balch, J.K., Bradley, B.A., D'Antonio, C.M., Gómez-Dans, J., 2013. Introduced annual grass increases regional fire activity across the arid western USA (1980-2009). Global Change Biol. 19, 173-183.

Brewer, J.S., 2011. Per capita community-level effects of an invasive grass, Microstegium vimineum, on vegetation in mesic forests in northern Mississippi (USA). Biol. Invasions 13, 701-715.

Brooks, M.L., D'Antonio, C.M., Richardson, D.M., Grace, J.B., Keeley, J.E., DiTomaso, J.M., Hobbs, R.J., Pellant, M., Pyke, D., 2004. Effects of invasive alien plants on fire regimes. Bioscience 54, 677-688.

Brown, J.K., 1974. Handbook for inventorying downed woody material. In. USDA For. Serv., Ogden, UT.

Burton, J.A., Hallgren, S.W., Fuhlendorf, S.D., Leslie, D.M., 2011. Understory response to varying fire frequencies after 20 years of prescribed burning in an upland oak forest. Plant Ecol. 212, 1513-1525.

Cheplick, G.P., 2010. Limits to local spatial spread in a highly invasive annual grass (Microstegium vimineum). Biol. Invasions 12, 1759-1771.

Christen, D.C., Matlack, G.R., 2009. The habitat and conduit functions of roads in the spread of three invasive plant species. Biol. Invasions 11, 453-465.

Claridge, K., Franklin, S.B., 2002. Compensation and plasticity in an invasive plant species. Biol. Invasions 4, 339-347. 
475 476

477

478

479

480

481

482

483

484

485

486

487

488

489

490

491

492

493

494

495

496

497

Craig, M.E., Pearson, S.M., Fraterrigo, J.M., 2015. Grass invasion effects on forest soil carbon depend on landscape-level land use patterns. Ecology, in press.

D'Antonio, C.M., Vitousek, P.M., 1992. Biological invasions by exotic grasses, the grass/fire cycle, and global change. Annu. Rev. Ecol. Syst. 23, 63-87.

Davis, M.A., Pelsor, M., 2001. Experimental support for a resource-based mechanistic model of invasibility. Ecol. Lett. 4, 421-428.

DeBano, L.F., Neary, D.G., Ffolliott, P.F., 1998. Fire effects on ecosystems. John Wiley and Sons Inc., New York, NY. 333 pp.

DeGasperis, B.G., Motzkin, G., 2007. Windows of opportunity: historical and ecological controls on Berberis thunbergii invasions. Ecology 88, 3115-3125.

Dibble, A.C., White, R.H., Lebow, P.K., 2007. Combustion characteristics of north-eastern USA vegetation tested in the cone calorimeter: invasive versus non-invasive plants. Int. J. Wildland Fire 16, 426-443.

Dibble, A.C., Zouhar, K., Smith, J.K., 2008. Fire and nonnative invasive plants in the Northeast bioregion.

Ehrenfeld, J.G., Kourtev, P., Huang, W.Z., 2001. Changes in soil functions following invasions of exotic understory plants in deciduous forests. Ecol. Appl. 11, 1287-1300.

Emery, S.M., Luke Flory, S., Clay, K., Robb, J.R., Winters, B., 2013. Demographic responses of the invasive annual grass Microstegium vimineum to prescribed fires and herbicide. For. Ecol. Manage. 308, 207-213.

Emery, S.M., Uwimbabazi, J., Flory, S.L., 2011. Fire intensity effects on seed germination of native and invasive Eastern deciduous forest understory plants. For. Ecol. Manage. 261, 1401-1408. 
Fairbrothers, D.E., Gray, J.R., 1972. Microstegium vimineum (Trin.) A. Camus (Gramineae) in the United States. Bull. Torrey Bot. Club 99, 97-\&.

Fischer, A., Marshall, P., Camp, A., 2013. Disturbances in deciduous temperate forest ecosystems of the northern hemisphere: their effects on both recent and future forest development. Biodivers. Conserv. 22, 1863-1893.

Flory, S.L., Clay, K., 2010. Non-native grass invasion alters native plant composition in experimental communities. Biol. Invasions 12, 1285-1294.

Flory, S.L., Lewis, J., 2009. Nonchemical methods for managing Japanese stiltgrass (Microstegium vimineum). Invasive Plant Science and Management 2, 301-308.

Flory, S.L., Long, F.R., Clay, K., 2011. Invasive Microstegium populations consistently outperform native range populations across diverse environments. Ecology 92, 22482257.

Fraterrigo, J.M., Strickland, M.S., Keiser, A.D., Bradford, M.A., 2011. Nitrogen uptake and preference in a forest understory following invasion by an exotic grass. Oecologia 167, 781-791.

Fraterrigo, J.M., Wagner, S., Warren, R.J., 2014. Local-scale biotic interactions embedded in macroscale climate drivers suggest Eltonian noise hypothesis distribution patterns for an invasive grass. Ecol. Lett. 17, 1447-1454.

Glasgow, L.S., Matlack, G.R., 2007. The effects of prescribed burning and canopy openness on establishment of two non-native plant species in a deciduous forest, southeast Ohio, USA. For. Ecol. Manage. 238, 319-329.

Gross, K.L., 1990. A comparison of methods for estimating seed numbers in the soil. J. Ecol. 78, 1079-1093. 
521 Heyward, F., 1938. Soil temperatures during forest fires in the longleaf pine region. J. For. 36, 478-491.

523 Hoffmann, W.A., Lucatelli, V.M., Silva, F.J., Azeuedo, I.N., Marinho, M.d.S., Albuquerque,

Huebner, C.D., 2010a. Establishment of an invasive grass in closed-canopy deciduous forests across local and regional environmental gradients. Biol. Invasions 12, 2069-2080.

Huebner, C.D., 2010b. Spread of an invasive grass in closed-canopy deciduous forests across local and regional environmental gradients. Biol. Invasions 12, 2081-2089.

Hughes, F., Vitousek, P.M., Tunison, T., 1991. Alien grass invasion and fire in the seasonal submontane zone of Hawai'i. Ecology, 743-747.

Iverson, L.R., Hutchinson, T.F., 2002. Soil temperature and moisture fluctuations during and after prescribed fire in mixed-oak forests, USA. Nat. Areas J. 22, 296-304.

Kourtev, P.S., Ehrenfeld, J.G., Haggblom, M., 2003. Experimental analysis of the effect of exotic and native plant species on the structure and function of soil microbial communities. Soil Biol. Biochem. 35, 895-905.

Kuhman, T., Pearson, S., Turner, M., 2010. Effects of land-use history and the contemporary landscape on non-native plant invasion at local and regional scales in the forestdominated southern Appalachians. Landscape Ecol. 25, 1433-1445.

Kuppinger, D., Kuppinger, M., Jenkins, P., White, 2010. Predicting the post-fire establishment and persistence of an invasive tree species across a complex landscape. Biol. Invasions 12, 3473-3484. 
544 Levitt, J., 1980. Responces of plants to environmental stresses, Vol 1. Chilling, freezing, and 545 high temperature stresses. XII+497P-XII+497P pp.

546 Marshall, J.M., Buckley, D.S., 2008. Influence of litter removal and mineral soil disturbance on 547 the spread of an invasive grass in a Central Hardwood forest. Biol. Invasions 10, 531$548 \quad 538$.

549 Marshall, J.M., Buckley, D.S., Franklin, J.A., 2009. Competitive interaction between 550 Microstegium vimineum and first-year seedlings of three central hardwoods. J. Torrey $551 \quad$ Bot. Soc. 136, 342-349.

552 Matlack, G.R., 2013. Reassessment of the Use of Fire as a Management Tool in Deciduous $553 \quad$ Forests of Eastern North America. Conserv. Biol. 27, 916-926.

554 McDonald, T.L., Erickson, W.P., McDonald, L.L., 2000. Analysis of count data from before555 after control-impact studies. Journal of Agricultural Biological and Environmental $556 \quad$ Statistics 5, 262-279.

557 Melvin, M.A., 2012. 2012 National prescribed fire use survey report. In. National Association of $558 \quad$ State Foresters and the Coalition of Prescribed Fires Councils.

559 Mohlenbrock, R.H., 1982. Woody plants of the Shawnee National Forest (Illinois). Castanea, 560 347-359.

561 Mohlenbrock, R.H., 1986. Vascular flora of Illinois. SIU Press, Carbondale, IL. pp.

562 Neary, D.G., Klopatek, C.C., DeBano, L.F., Ffolliott, P.F., 1999. Fire effects on belowground sustainability: a review and synthesis. For. Ecol. Manage. 122, 51-71.

564 Nelson, J.L., Groninger, J.W., Ruffner, C.M., Battaglia, L.L., 2009. Past land use, disturbance 565 regime change, and vegetation response in a southern Illinois bottomland conservation $566 \quad$ area. J. Torrey Bot. Soc. 136, 242-256. 
Oswalt, C.M., Oswalt, S.N., 2007. Winter litter disturbance facilitates the spread of the nonnative invasive grass Microstegium vimineum (Trin.) A. Camus. For. Ecol. Manage. 249, 199203.

570

571

572

573

574

575

576

577

578

579

580

581

582

583

584

585

586

587

588

589

Oswalt, C.M., Oswalt, S.N., Clatterbuck, W.K., 2007. Effects of Microstegium vimineum (Trin.) A. Camus on native woody species density and diversity in a productive mixed-hardwood forest in Tennessee. For. Ecol. Manage. 242, 727-732.

Rauschert, E.S.J., Mortensen, D.A., Bjornstad, O.N., Nord, A.N., Peskin, N., 2010. Slow spread of the aggressive invader, Microstegium vimineum (Japanese stiltgrass). Biol. Invasions 12, 563-579.

Ross, K.A., Ehrenfeld, J.G., Patel, M.V., 2011. The effects of nitrogen addition on the growth of two exotic and two native forest understory plants. Biol. Invasions 13, 2203-2216.

Royo, A.A., Collins, R., Adams, M.B., Kirschbaum, C., Carson, W.P., 2010. Pervasive interactions between ungulate browsers and disturbance regimes promote temperate forest herbaceous diversity. Ecology 91, 93-105.

Ryan, K.C., Knapp, E.E., Varner, J.M., 2013. Prescribed fire in North American forests and woodlands: history, current practice, and challenges. Front. Ecol. Environ. 11, e15-e24.

SAS Institute Inc., 2013. The SAS system for Windows. Release 9.3. SAS Institute, Cary, NC, USA.

Setterfield, S.A., Rossiter-Rachor, N.A., Hutley, L.B., Douglas, M.M., Williams, R.J., 2010. Turning up the heat: the impacts of Andropogon gayanus (gamba grass) invasion on fire behaviour in northern Australian savannas. Divers. Distrib. 16, 854-861.

Stambaugh, M.C., Varner, J.M., Noss, R.F., Dey, D.C., Christensen, N.L., Baldwin, R.F., Guyette, R.P., Hanberry, B.B., Harper, C.A., Lindblom, S.G., Waldrop, T.A., 2015. 
Clarifying the role of fire in the deciduous forests of eastern North America: reply to Matlack. Conserv. Biol., 1-5.

592 Touchette, B.W., Romanello, G.A., 2010. Growth and water relations in a central North Carolina 593 population of Microstegium vimineum (Trin.) A. Camus. Biol. Invasions 12, 893-903.

594 USDA, NRCS, 2015. The PLANTS Database. In. National Plant Data Team, Greensboro, NC.

595 Ward, J.S., Mervosh, T.L., 2012. Nonchemical and herbicide treatments for management of Japanese stiltgrass (Microstegium vimineum). Invasive Plant Science and Management 5, 9-19.

598 Warren, R.J., Bahn, V., Bradford, M.A., 2012. The interaction between propagule pressure, habitat suitability and density-dependent reproduction in species invasion. Oikos 121,

600 874-881.

601 Warren, R.J., Bahn, V., Kramer, T.D., Tang, Y., Bradford, M.A., 2011. Performance and reproduction of an exotic invader across temperate forest gradients. Ecosphere 2, 14-19.

603

604 
Figure 1

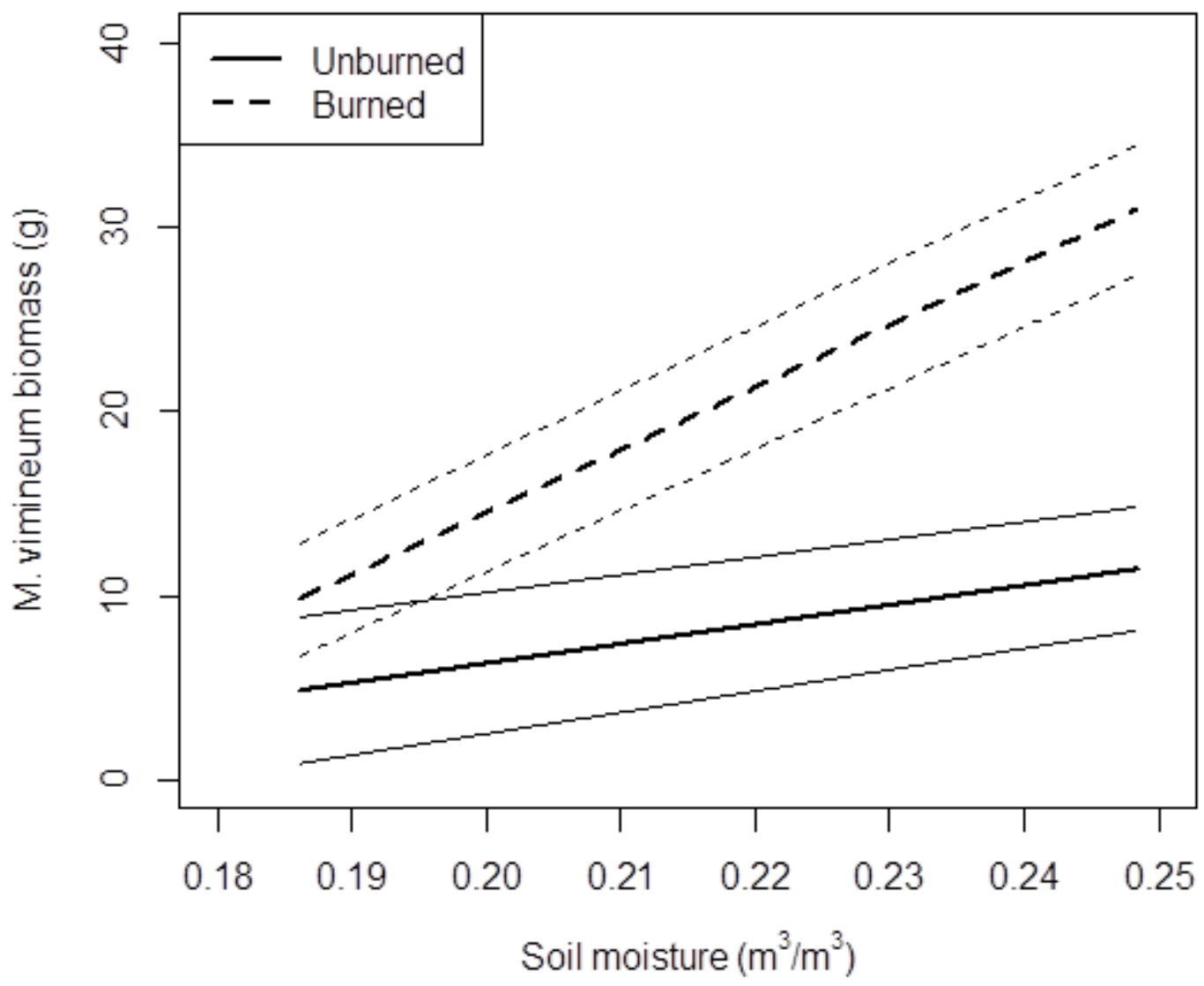


Figure 2
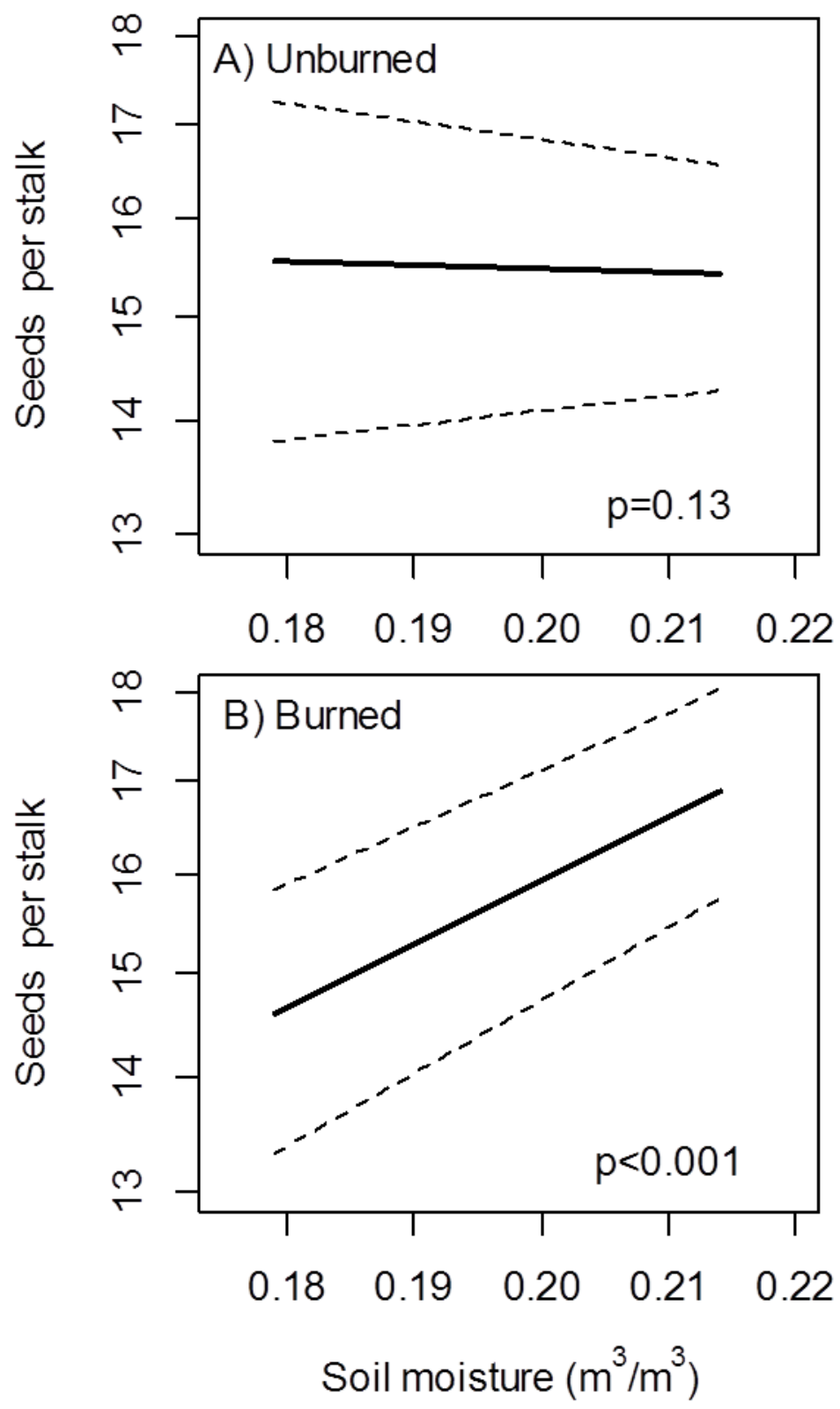
Figure 3

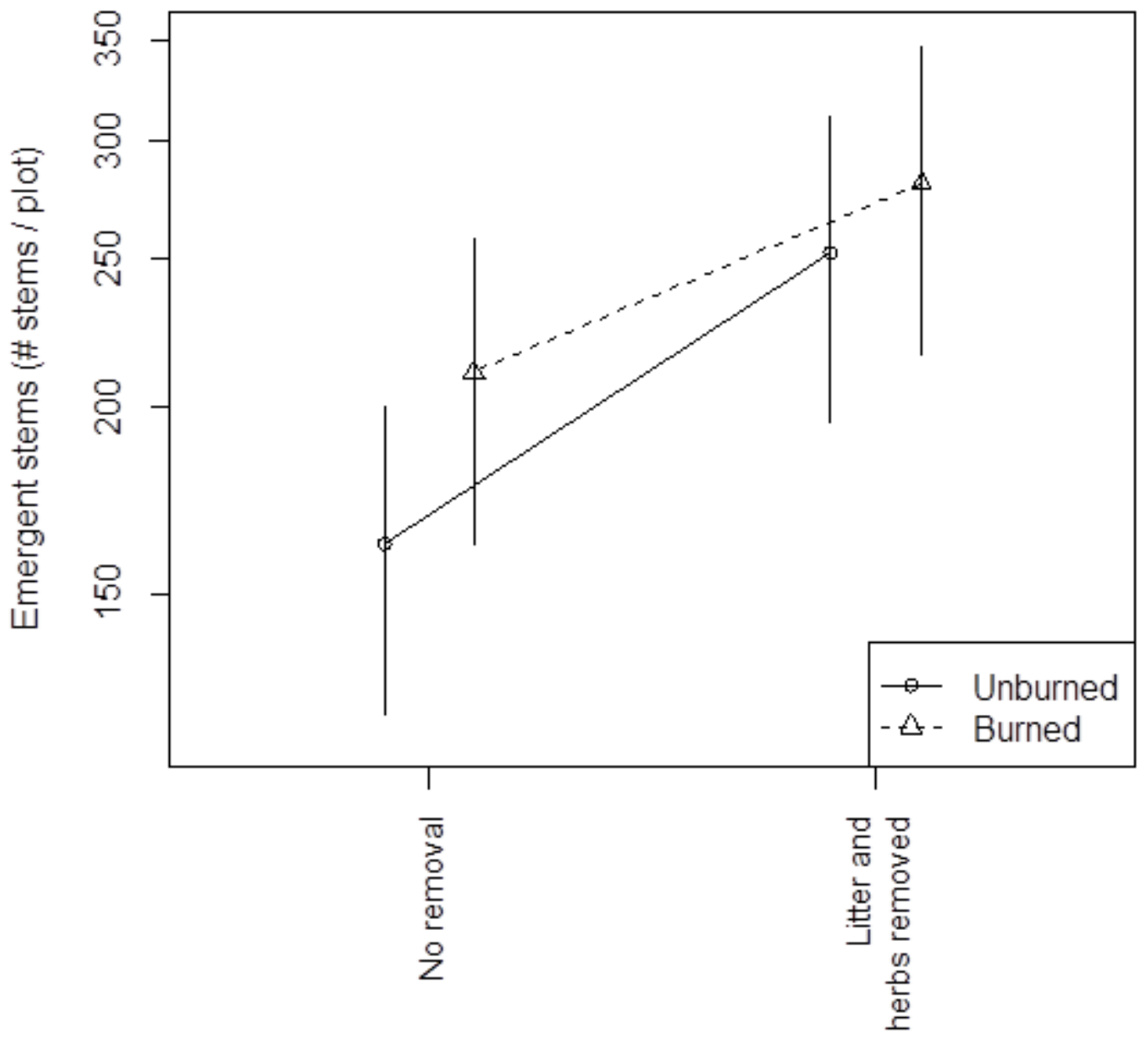


